\title{
Data Derives: Confronting Digital Geographic Information as Spectacle
}

\author{
Jim Thatcher and Craig M. Dalton
}

\section{Introduction - The Spectacle of Data}

'[W]e are sitting at home, participating in an information economy in which we consume mediated realities from the screen and produce our own mediated realities for the databases' (Bachler 2013, 32) ${ }^{1}$

We live in a world in which code, algorithms, and data mediate, saturate, and sustain global capitalism (Graham, 2005). Smartphones, credit card logs, official records, and a variety of other sur- and sous-veillant systems attempt to transform everyday life into a series of quantifiable data sets (Berry 2011). Data generated through quotidian daily practices, such as searching for a nearby restaurant on Yelp, is dispossessed from the data creator and linked together with billions of other data points in ways which come to stand for the individuals represented by said data (Thatcher et al. 2016).

This is a chapter about critically engaging the data of everyday life - that data created through the daily, mundane use of mobile phones, store loyalty cards, bus passes, and other banal trappings of late capitalist modernity. To do so, we

How to cite this book chapter:

Thatcher, J. and Dalton, C. M. 2017. Data Derives: Confronting Digital Geographic Information as Spectacle. In: Briziarelli, M. and Armano, E. (eds.). The Spectacle 2.0: Reading Debord in the Context of Digital Capitalism. Pp. 135-150. London: University of Westminster Press. DOI: https://doi.org/10.16997/book11.h. License: CC-BY-NC-ND 4.0 
first argue that data functions as a commodity in two ways within what we, following Gregg (2014), call the data spectacle. Data is first produced as a commodity, a site for speculative capital investment, and second as the quantified, spectacularised representation of self, reflected back at individuals from the data they generate. The latter is part of the emerging 'quantified self-city-nation' (Wilson 2015), an 'entangled socio-technical mesh through which individuals both come to know and are made known, sorted, and (in)visible to themselves and society' (Thatcher 2016,4).

Through data, capital colonizes not only everyday life, but the very representations of the self. To confront this, we argue for a return to one of the earliest psychogeographic practices of the Situationists, the dérive. Building on the dérive and on the more recent work of the Precarias a la Deriva collective, we propose a data dérive as a praxis that begins the reclaiming of time, space, and self from the presentations and representations of the data spectacle.

\section{The Double Role of Data Within the Spectacle}

The spectacle is not a collection of images; it is a social relation between people that is mediated by images. (Debord 1967, Thesis 4)

One problem with attempts to write definitively of the Situationists is that it was a group organized against such definitives. Contradictions emerge within their thought both intentionally and due to interpersonal conflict and splintering. We do not seek to write a history of the Situationists as several already exist (see, inter-alia, Wark 2011; Plant 1992; Marcus 1989 for various engagements), nor to present our interpretations of Situationist thought as austere, objective truths; what we write is only our partial interpretations thereof. As Wark (2011, 73) notes, within the corpus of the Situationists, everyone has their favorites, 'champions' who they hoist out as representative of the whole. Here, our goal is to develop a specific interpretation of the spectacle and how it has come to function through the data of everyday life, first following Gregg's explication of the scopophilic nature of the data spectacle as a tool for imagining 'command and control through seeing' (Gregg 2014, 37 following Halpern 2014), and then extending that idea through the colonization of everyday life through data (Thatcher et al. 2016). We begin with our cobbled together, detourned spectacle.

The modern spectacle, for Debord, is the autocratic reign of the market economy which had acceded to an irresponsible sovereignty, and the totality of new techniques of government which accompanied this reign' (Debord $1998,2)$. 'It is the generalization of private life' (Lefebvre in Wark 2011, 104) that emerged when the commodity form was 'no longer something that enters into the sphere of experience in fulfilling particular needs or desires, but has itself become the constituent of the world of experience' (Chu and Sanyal 2015, 399). Like the culture industry, the spectacle presents continual false choices 
as a means of provoking continual consumptive practices (Horkheimer and Adorno 2002). For Debord it is also something more, a totality in which all life occurs and through which all life is experienced.

For some, like Mitchell (2008), the totality of the spectacle overstates the nuances of lived experience and therefore weakens its conceptual utility, reducing it to an obvious intellectual fetish by which critical theorists may toss water balloons at the armoured tanks of capitalist modernity. Le Monde noted this irony of critiquing the spectacle from within its totality in 1987: 'That modern society is a society of the spectacle goes without saying ... What is so droll, however, is that all the books which do analyse this phenomenon, usually to deplore it, cannot but join the spectacle if they're to get attention' (in Debord 1998, 5). However, such views mistake a totalizing tendency for static totality. The point of the spectacle is that it dynamically colonizes and subjugates daily life at all levels of experience and at all times. In so doing, it 'rigidly separates what is possible from what is permitted' (Debord 1967, Thesis 25).

New technological forms, especially for communication and industrial organization, make this possible (Debord 1967, Thesis 24), but it is also through the technicity of new technology that the spectacle may be contested. Whilst Ranciére correctly observes that 'there is no straightforward road from the fact of looking at a spectacle to the fact of understanding the state of the world' and that the very ubiquity of the detournement of images has muted their power, if it ever existed (Ranciere 2011, 75). He is making an observation which Debord and Constant (Nieuwenhuys) had already realized in the 1960s. Constant's New Babylon accepts technicity, that 'co-constitutive milieu of relations between the human and their technical supports' (Crogan, P. and Kennedy, H. 2009 cited in Bucher 2012, p. 4), as the key means by which to think the 'possibilities of social and technical transformation together' (Wark 2011, 145). The spectacle then emerges through and with technology and must be contested through and with its technicity. With this duality in mind, we turn to Gregg's extension of the spectacle into data.

\subsection{Data as the Site of Speculative Investment}

The blindness and muteness of the data to which positivism reduces the world passes over into language itself, which is limited to registering those data (Horkheimer and Adorno 2002, 135).

Much like Le Monde's observation of the banality of the spectacle's totality, it now seems almost quaint to argue that data has become a site for massive speculative investment. Data has become the 'de facto standard through which the world is ordered and understood,' with 'Big Data' emerging as a paradigmatic epistemology through which cities, science, business, and much else can and must be understood (boyd and Crawford, 2012). Sometimes referred to as the 
'fourth paradigm' for science (Kitchin 2014, 130), at an extreme this approach to knowledge production creates a state of 'knowing without understanding' (Andrejevic 2013, 26) wherein 'numbers speak for themselves' (Anderson 2008) amidst a naïve 'pseudopositivist' understanding of quantification (Wyly 2014, 30).

This hubristic orientation towards a world known totally through 'Big Data' has been the subject of many critiques in both the popular and academic presses. New data systems, especially those that link location and temporal information, have been investigated as 'fixes' for capitalism's tendencies towards overaccumulation (Greene and Joseph 2015), their historical entanglement in social physics and geodemographic profiling examined and their role and function as a commodity explored in detail (Barnes and Wilson 2014; Dalton and Thatcher 2015). While much (often digital) ink has been spilled regarding the fallacies and capitalist imperatives at the heart of new data accumulation and analysis regimes (not the least of which is our own), this recognition has done little to curb either the generation of said data or its valuation as a commodity. At the time of writing, IBM has estimated that mobile device use generates slightly over five petabytes of data a day (IBM 2013), or roughly the yearly amount of data generated by the Large Hadron collider each week (Dalton et al. 2016). Snap Inc., a single corporation whose application creates, extracts, and analyses data through its use, is currently planning an IPO valuation at around twentyfive billion dollars (Farrell et al. 2016).

This push towards a flat, quantified rendering of the world in numbers is hardly new (Foucault, 2008; Scott, 1998), but as the growth in both the size of new data systems and their valuation continues unabated, these new systems, and the epistemological orientation towards the world they entail, move towards a new societal totality. Gregg (2014) connects one aspect of these new systems with a new form of the spectacle, what she terms the data spectacle. Drawing on Halpern (2014), Gregg $(2014,37)$ suggests that the data spectacle emerges from the 'aesthetic pleasure and visual allure of witnessing large data sets at scale.' A modernist 'visual rhetoric' produces this scopophilic pleasure in which data requires only 'the indication of potential to achieve veracity' (Gregg 2014, 39, 40). Studying the professional world of Big Data engineers and conferences, Gregg correctly sees a future data spectacle built around the 'fantasy of command and control through seeing' (ibid., 37). Such Big Data visualizations and systems seek to produce a world in their own image rather than simply interpret an existing one (Kitchin et al. 2015). In their leveraging of massive interlinked data sets, they offer a disembodied, apparently omniscient god's eye view of that world (Haraway 1991; Kingsbury and Jones, 2009). While this desire and its limitations have precedents, what is new are the types of data being leveraged and the scales at which these systems operate.

Gregg's article seeks to advance 'an ethical data economy', one that understands both 'the assembly of data and its capacity to act on our behalf' (2014, 47). She admits that her own vision of the data spectacle is 'certainly more 
optimistic than my reference to Debord's Society of the Spectacle would imply' $(2014,39)$ and firmly situates her data spectacle within the visual fantasies of top-down command and control that ideologically underpin such presentations of 'Big Data.' There are overlapping structural and affective similarities to these modernist fantasies and their accompanying scopophilic pleasures with the creation and use of maps. ${ }^{2}$ However, due to this focus, Gregg's definition of the data spectacle remains incomplete. By rooting the data spectacle in a top down performance by and for engineers and other elites, Gregg's spectacle misses the scalability of the data spectacle and and the fact that it is increasingly situated and embodied (Wilmott 2016, 4). The 'data of everyday life' (Thatcher 2016), when produced in situated practice, collected in bulk, synthesized together, algorithmically analysed, and served back into everyday practice gives rise to the 'quantified self-city-nation' (Wilson 2015). The data spectacle is just as much about the mediation of everyday lived experience as it is any Big Data dashboard or algorithm. The quotidian nature of the data that constitutes much of the data spectacle serves as the second move for our definition.

\subsection{The Colonization of Everyday Life in Data}

We have thus moved beyond the theorization of our mobile devices as a type of prosthetic to our bodies ... but instead have to conceive of our devices as absolutely integral to the very foundations of embodied space in the digital age (Farman 2012, 46)

In the latter half of her piece on the data spectacle, Gregg attempts to understand the 'work that data does on our behalf' and puts forth the concept of data sweat as a means of moving past the data shadow and the 'ocular-centric ideas of information sovereignty' it entails (Gregg 2014, 38, 45). Whether data sweat or data fumes (Thatcher 2014), Gregg correctly notes the need to move beyond a singular visual metaphor by which Big Data visualizations function. Something more is occurring with respect to the data created by and through the quotidian practices that have developed around smart-device use (Ash et al. 2016.

On the one hand, 'the linked data about the individual comes to stand for the individual who created it' as the 'individual that capital can see' (Thatcher et al. 2016, 9). This is the epistemic leap from data to individual that lies at the heart of Big Data's mythology, it is the scopophilic pleasure of top-down control through the data spectacle, and it is the hubristic claim of numbers speaking for themselves. On the other hand, this digital individual of modelled consumptive patterns is not simply reflected back at the person it (re)presents, but rather tracks, shapes, and delimits the very options presented to and actions taken by said person. Ostensibly pleasurable experiences and notional advantages are offered in exchange for the production and extraction of their data. 
As previously private moments and decisions, such as what restaurant to visit or which potential sexual partner to contact, are mediated via data producing and capturing technologies, daily life becomes further colonized by capitalist interests (Thatcher et al. 2016). The data generated by such actions is then fed back into analytic systems which algorithmically shape what options will be presented to the person the next time (s)he makes use of the service (Graham 2005). This process creates howling feedback loops through which lived experiences are channelled and collected in pursuit of smooth, predictable consumption (Thatcher 2013; Wilson 2012).

This howling feedback loop, by which data is created through an action that is then fed into the system to influence future actions, is part of late capitalism's 'corporeal corkscrewing inwards' (Lohr 2012; Beller 2012, 8). Not only does the data economy spring as a site for speculative capitalist investment, a potential 'fix' for systems of overaccumulation (Leszczynski 2014; Wilson 2012; and elsewhere), but also as individuals come to know, are made known, sorted, rendered visible (or not) to both themselves and others (Thatcher 2016). This entangled mesh expands across scales and suffuses quantification and capital imperatives into previously private times and spaces (Wilson 2015). It is the sleek, predictable, inexorably better world promised by this socio-technical milieu (Morozov 2014) that has colonized daily life.

Our definition of the data spectacle, then, recognizes it as a totalizing ideology, one built upon a series of myths in which the world can (and is) rendered flat, smooth, and calculable; one where the pursuit of ever-larger datasets is both inexorable and always productive of better interpretations, better understandings of the world. But, in the ways that this spectacle accumulates and is created through the data of everyday life, in the ways that it is made scalable, embodied, situated, and partial (Wilmott 2016), it is always open to contestation through that 'co-constitutive milieu' of humans and their use of the technologies they create. While there are other ways to break apart the seeming totality of 'Big Data' (See, for example, work on data assemblages as in Kitchin 2014, Kitchin and Lauriault 2014, and elsewhere), it is through the Situationist practice of the dérive that we find the ability to 'attack the 'enemy' at his base, within ourselves' (Trocchi 1964 in Marcus 1989, 173), to begin to contest that 'corporeal corkscrew inwards.'

\section{Drifting Towards Data}

Now the city would move like a map you were drawing; now you would begin to live your life like a book you were writing (Marcus 1989, 166)

In the 1950s, as Paris prepared for yet another top-down infrastructural redesign, Debord and other Situationists developed and deployed the method of dérive (drifting). Drawing from Ivan Chtcheglov and the inhabitants of postwar Saint-Germain, the Situationist dérives meant to study 'the colonization of 
everyday life at the heart of empire' (Wark 2011, 22). It was a rigorous, methodological praxis through which ' $\mathrm{t}$ ] he city would no longer be experienced as a scrim of commodities and power' but rather as the means of achieving an 'epistemology of everyday time and life' (Marcus 1989, 164). Specifically, they developed the dérive as a radical approach to understand urban psychogeography: the structure of cities in their continuities of ambience, nexuses, connections and barriers (fig. 1) (Debord 1955; 1956; Khatib 1958). The dérive was an 'active type of flâneurship whereby the formerly aristocratic walker was transformed into a conscious, political actor' (Flanagan 2008, 3).

Unfortunately, the dérive had almost no effects on the material redevelopment of the Parisian landscape in the late 1950s. Its importance, though, lies not in the failed restructuring of Paris, but as a critical method - the dérive involves an active frame of mind, sensitive to and engaging with the lived city as driving and shaped by the processes of capital. It was an approach to 'provoke critical notice of the totality of lived experience and reverse the stultifying passivity of the spectacle' (Plant 1992,60). While it may have failed at achieving the latter in any structural way, the importance of the dérive as method is clear in the multiple subsequent psychogeographical investigations (Bonnett 1992; Pinder 1996; Bassett 2004; Wood 2010). Given that Debord saw his theory of the dérive as necessarily incomplete, we propose a data dérive as an extension of two branches of Situationist-influenced thought and praxis: First, the modified drifting of Precarias a la Deriva, and second, the colonization of everyday life by data that has come to function as the data spectacle. Our data dérive synthesis is a means of becoming aware of and confronting 'data doubles' (Haggerty and Ericson 2000) and, in so doing, examining that 'negative space between an individual and their digital representation' (Dalton et al. 2016, 4).

Precarias a la Deriva (Precarious Women Adrift), is a feminist radical collective based in Spain. The purpose of their work is to better understand the circumstances of and build situated resistances and radical solidarities among precarious women workers on the margins of traditionally male, union-centered jobs and labour organizing. This kind of work often involves women labouring in temporary jobs, part-time work, and per-hour contracts, working in domestic circumstances, telemarketing, food service, healthcare, advertising, education, prostitution, and research. Given that such labour tends to be decentralized is often unregulated, how is it possible to resist? 'What is your strike?' (Precarias a la Deriva 2003). The dérive offers a critical way to engage such spatial and social issues. 'We opted for the method of the drift as a form of articulating this diffuse network of situations and experiences, producing a subjective cartography of the metropolis through our daily routes.'(ibid.)

Unlike the Situationist dérive, often practiced by privileged men and lacking a destination, Precarias' drifting works from each member's situated position. 'In our particular version, we opt ... for a situated drift which would move through the daily spaces of each one of us, while maintaining the tactic's multisensorial and open character' (ibid.). A member of the collective would lead 


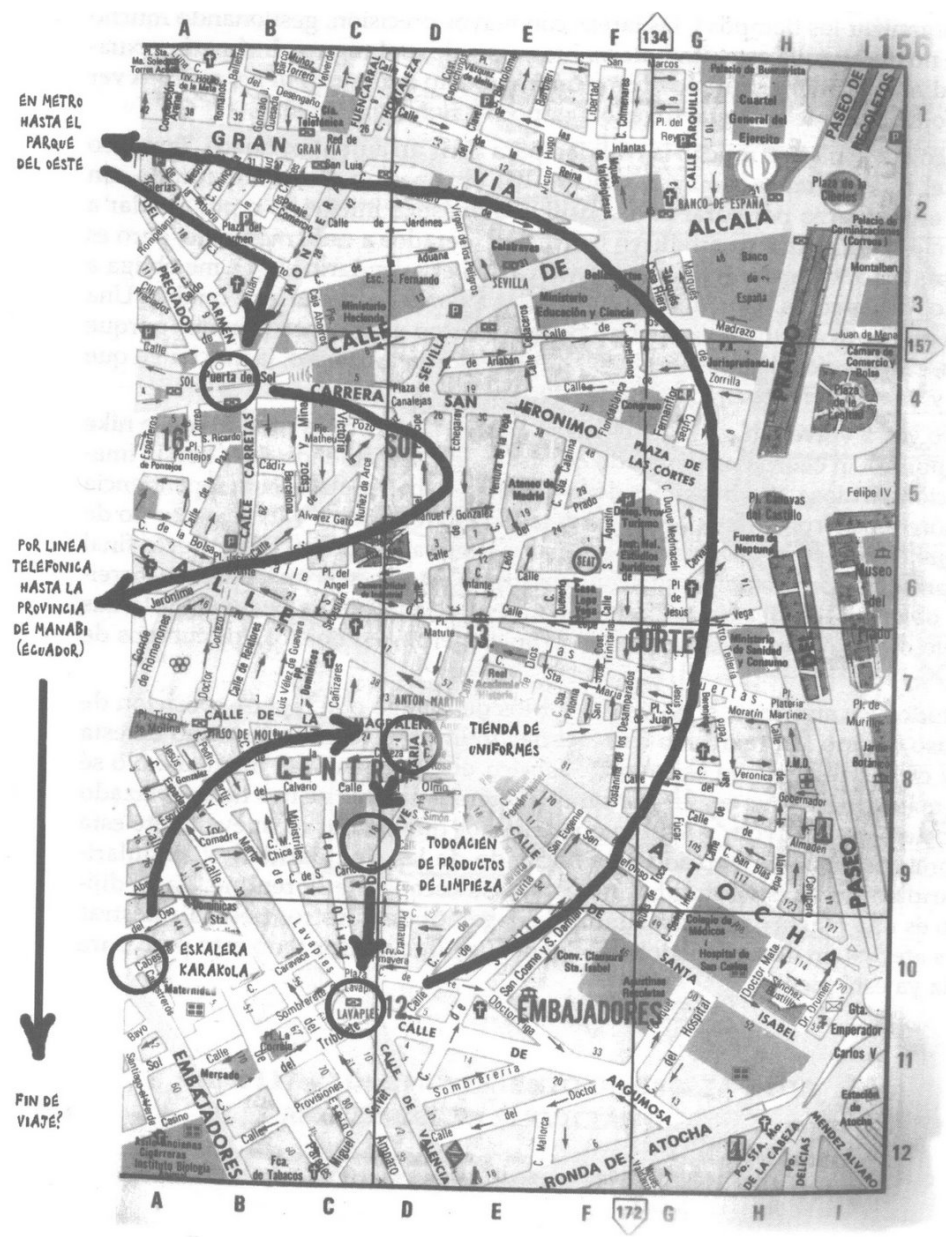

Fig. 1: Precarias a la Deriva showing their drift with domestic workers through the workers' everyday lives in Madrid. Precarias a la Deriva.

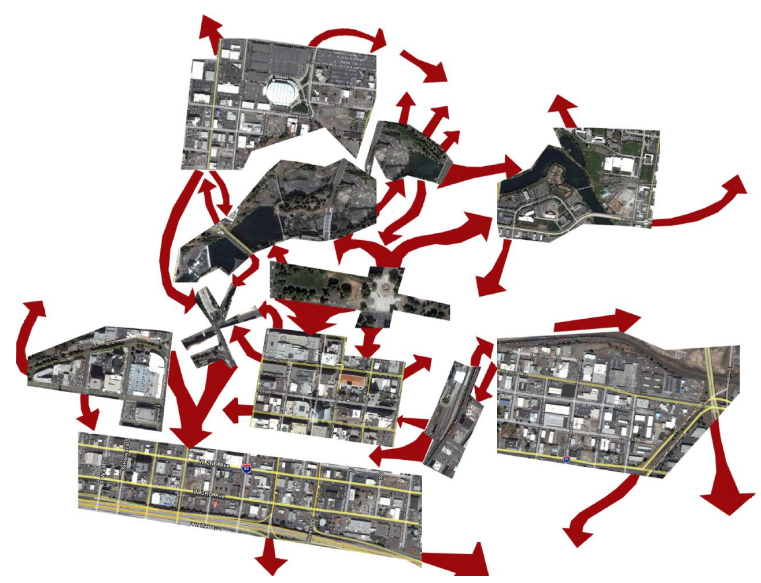

Fig. 2: A situationist-inspired map depicting the results of the dérive method in Spokane, WA. Jenny Cestnik. 
a group of drifters through her daily practices and work. As a group, all would reflect on and talk about conditions and resistances along the way. By travelling along and engaging in discussions and co-interviews, drifters could better understand each other's situations and forms of labour, making it possible to share coping mechanisms and building mutual radical awareness and solidarity. 'Thus, the drift is converted into a moving interview, crossed through by the collective perception of the environment.' (ibid.; Precarias a la Deriva 2006).

The work of Precarias a la Deriva brings a sensitivity to people's situations and practices, in particular social production, to the dérive frame of mind. Such a dérive is not limited to the environment of the city, but also includes the multitude of people and relations that constitute it through practice. Debord noted that the 'most fruitful numerical arrangement' for the dérive consisted of small groups. Precarias a la Deriva integrate the standpoint and experiences of a drifter's everyday life directly into the small group's drift itself. Their dérive is about coming to know the spaces of labour and the (often invisible) lives of those who work in them. Where Sadler $(1999,98)$ suspects the first dérives were also moments for dialectical discourse, Precarias a la Deriva makes this function explicit. Furthermore, where Debord and Sadler both see the dérive as functioning best when groups are composed of the like-minded, Precarias a la Deriva opens the dérive as an act for the forming of shared radical subjectivities. By following member/workers, Precarias a la Deriva makes legible their lived experiences and resistances.

The data dérive we propose builds from Precarias a la Deriva's version of the dérive in such a way as to confront and counter the data spectacle. It does so by combining exploration of environments with an investigation of the radical alternative possibilities hidden within the contexts of our daily (digital) lives. The key theoretical move for the data dérive is a recognition of the separation between the depth and nuance of an individual's lived experience and the data produced by those experiences. In other words, the data dérive confronts the data spectacle by attuning its participants to the epistemological leap between individual and data and, in so doing, it creates spaces for radical contestations of capitalism's colonization of ourselves. There is no strict form for a data dérive and, like Debord's dérive, we do not view this guide towards it to be a definitive or final statement; however, we can think of several ways a data dérive might occur, and in defining it as precisely as possible we hope to inspire more.

\section{Drifting Through Data}

$O$, gentlemen, the time of life is short! ... An if we live, we live to tread on kings. (Shakespeare, Henry IV as quoted in Debord 1967)

To better know the roles which data play in our lives and to possibly identify radical alternatives, even if only temporary solidarities or resistances, the data 
dérive requires an examination of data. Further, if it is to contest the data spectacle and the corporeal corkscrew of late capitalism into our lives, the commodification of previously private times, places, and actions, then it also requires an examination of data that appears to stand for an individual. To work from a particular person's situation and due to privacy concerns, we recommend that data dérives use the data of a participant. What this might entail, then, is an exploration of the contours of one of the dérive member's data history. Take for example the digital data of a Google Maps Timeline, which, when given permission, will track and make available the complete movement history of a mobile phone. ${ }^{3}$ Although these maps strive for accuracy, they are often of a point-to-point nature, capturing where an individual has spent time, rather than the specific courses they took to get from place to place.

Figure 3 represents a partial day in one of the authors' lives. As can be seen, Jim appears to have driven in a path that leads through parks, buildings, and even a residential liberal arts campus in a path between a coffee shop and back. From this, Google correctly infers that Jim likes coffee and, specifically, likes that coffee shop. As an author, Jim can testify that he does like their coffee, though even without that statement, the data is sufficient for the purposes of both targeting ads at him and selling his amalgamated digital personality to other advertisers (Dalton and Thatcher 2015). This is only part of the data spectacle's rendering of Jim on that day. A data dérive might confront this rendering by traversing the route specified, but this time actually walking across and around the buildings and parks which were obviously never part of the original route. In this way, dérive participants might better understand the spaces of their lives as filled with different ambiances, swirls, and psychogeographical effects that exist within the actually existent environment. Further, while doing so, the drifter whose data is being followed can and should conduct a dialogue with other participants over what spaces, what moments, were selected as destinations within the data. Why this coffee shop and not that? Why a right turn here and a left there? How is that coffee shop important to your productivity? Given the geographical distribution of your labour, what is your strike?

As geographers, we focus our example upon spatial data and the spatial experience. Drawing from psychogeographical praxis, this makes sense, but it is not to imply that the data dérive must use spatial data or involve moving through space. Debord noted the possibility for a 'static-dérive' and this is certainly possible with data. The data of everyday life need not be spatial, for example an individual might download their entire Facebook history and decide to drift through it - exploring, asking, and answering about the state of their life in relation to the data. The point that cannot be removed, though, is that in order to confront the data spectacle, the data must be the data that has come to stand for an individual within it. Our data dérive, and we are not so arrogant as to think that our methods are the only ones possible, is aimed at confronting the data that continually attempts to define individuals and shape their lives in myriad seen and unseen ways. It is a confrontation with the 'quantified self - city - nation.' 


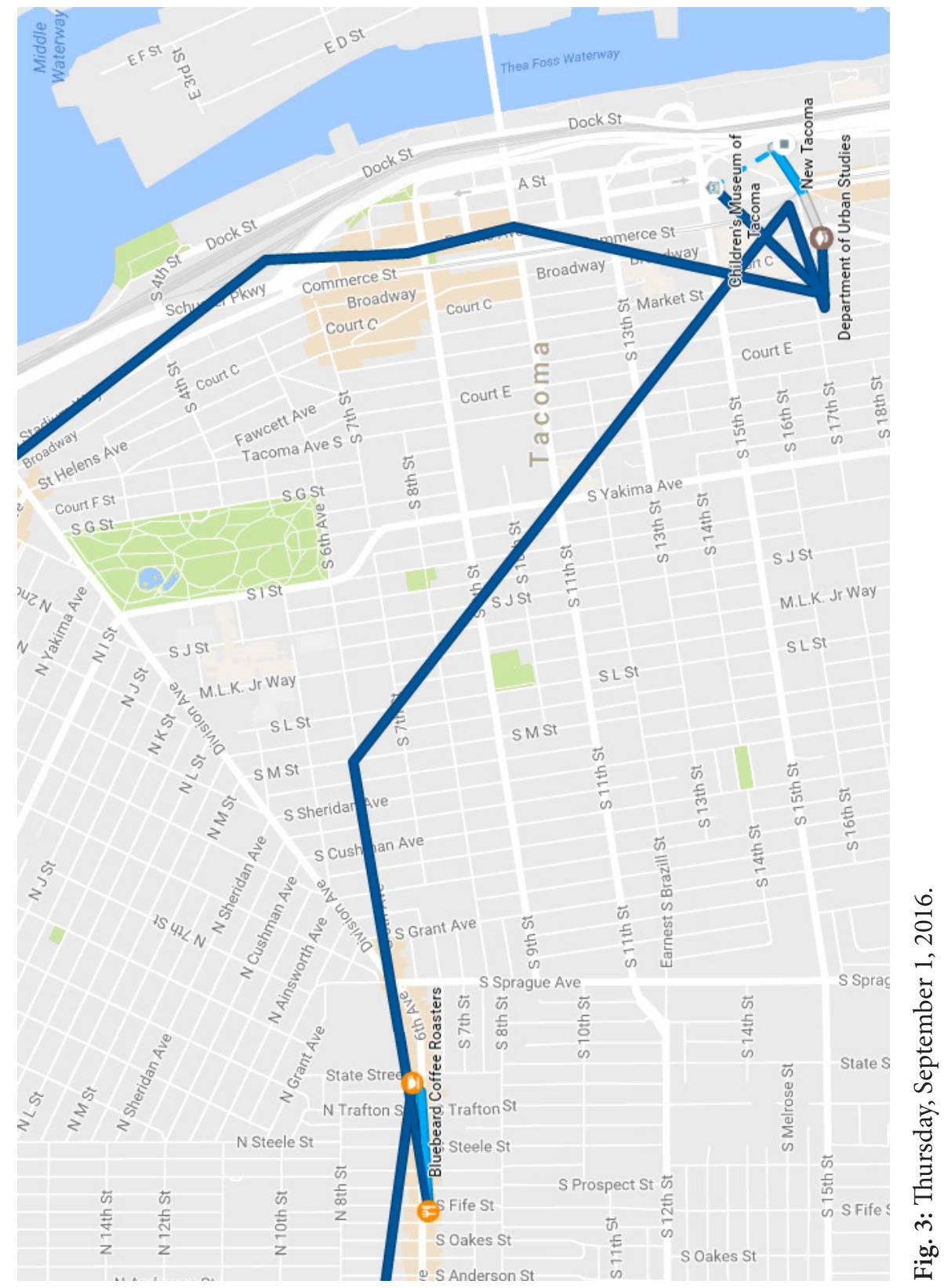


Confronting something so personal can be a terrifying and intimidating process. We do not control and certainly do not fully know what data exist within the estimated 1,500 data points Acxiom has collected on hundreds of millions of individuals (Singer 2012). What is revealed may be unpleasant or difficult to face, it may be wrong or embarrassing. But, as Trocchi writes in 1964, we must 'attack the 'enemy' at his base, within ourselves' (in Marcus 1989, 173). On the one hand, such discomfort and danger was always a part of the dérive, a disorienting, at times inebriated, and exhausting affair. On the other hand, as a method for producing intersubjective awareness and alliances, it is necessary to acknowledge that not all individuals exist with the same privileges amidst the data spectacle. We are able to release Figure 3 because of our relatively privileged position, because the knowledge of what coffee shop Jim attended and what parks are near his office does not endanger him in any way. This is not true for all data about all individuals. As Flanagan $(2009,206)$ writes, the 'drift' for many is not one of exploration or privilege, but a search for a place to sleep or for labour.' Precarias a la Deriva grapples with this uneven relation and makes it a source of potential understandings and alliances. It is for this reason that we read our dérive through their development of the method. We call for a data dérive, for resisting the data spectacle, for confronting the gap between an individual and the data that stands for them, for creating spaces of critique, and we view it as only one of potentially many.

(To be continued ...)

\section{Notes}

1 We begin each section with a brief epigraph to both introduce the discussion and to highlight the wealth of critical thinking around digital technologies and data. In some sense, they are intended as inspiration for theoretical drifting akin to the flexibility espoused by Lyotard in his later works.

2 While it has been impossible to fully address critical cartography in this chapter, for various explorations of the affective, structural, state, and databased biases and powers found in the production and uses of maps, see, inter-alia, Harley (1989), Godlewska (1989), Wood (1992), Schulten (2001), Pickles (2004), Parks (2005), Pavlovskaya (2006), Sieber (2006), Kitchin and Dodge (2007), Propen (2009), Rose-Redwood (2015) and elsewhere.

3 Many users may have this 'feature' turned on unsuspectingly. Regardless, it can be found at: https://www.google.com/maps/timeline

\section{References}

Anderson Chris. 2008. 'The End of Theory: The Data Deluge Makes the Scientific Method obsolete.' Wired 16(7): 2-6. 
Ash, James, Rob Kitchin, and Agnieszka Leszczynski. 2016. 'Digital Turn, Digital Geographies?' Progress in Human Geography DOI: https://doi. org/10.1177/0309132516664800

Bachler, Birgit. 2013. 'Like Reality'. Leonardo Electronic Almanac 19(4), 26-33.

Barnes, Trevor J and Matthew W Wilson. 2014. 'Big Data, Social Physics, and Spatial Analysis: The Early Years.' Big Data \& Society 1(1): 1-14.

Bassett, Keith. 2004. 'Walking As an Aesthetic Practice and a Critical Tool: Some Psychogeographic Experiments.' Journal of Geography in Higher Education 28(3): 397-410.

Berry, Dave. 2011. The Philosophy of Software: Code and Mediation in the Digital Age. Houndmills: Palgrave-Macmillan.

Bonnett, Alastair. 1992. 'Art, Ideology, and Everyday Space: Subversive Tendencies from Dada to Postmodernism.' Environment and Planning D: Society and Space 10(1): 69-86.

boyd, Dannah and Kate Crawford. 2012 'Critical Questions for Big Data.' Information, Communication and Society 15(5): 662-679.

Bucher, Taina. 2012. 'A Technicity of Attention: How Software 'Makes Sense" Culture Machine 13: 1-23.

Chu, Cecilia L. and Romola Sanyal. 2015. 'Editorial: Spectacular Cities of Our Time.' Geoforum 65: 399-402.

Dalton, Craig M. and Jim Thatcher. 2015. 'Inflated Granularity: Spatial 'Big Data' and Geodemographics.'Big Data \& Society. July-December 2015: $1-15$.

Dalton, Craig M., Linnet Taylor, and Jim Thatcher. 2016. 'Critical Data Studies: A Dialog on Data and Space.' Big Data \& Society January-June 2016: 1-9.

Debord, Guy. September 1955. 'Introduction to a Critique of Urban Geography' Trans. Ken Nabb. Les Lèvres Nues \#6. Available at: http://www.cddc. vt.edu/sionline/presitu/geography.html

Debord, Guy. November 1956. 'Theory of the Dérive.' Trans. Ken Knabb. Les Lèvres Nues \#9 Available at: http://www.cddc.vt.edu/sionline/si/theory. html

Debord, Guy. 1967. The Society of the Spectacle. Trans. Ken Knabb. London, UK: Rebel Press.

Debord, Guy. 1998. Comments on the Society of the Spectacle. London: Verso.

Farman, Jason. 2012. Mobile Interface Theory: Embodied Space and Locative Media. New York: Routledge.

Farrell, Maureen, Juliet Chung, and Rolfe Winkler. 2016. 'Snapchat Parent Working on IPO Valuing Firm at \$25 Billion or More.' The Wall Street Journal. Available at: http://www.wsj.com/articles/snapchat-parent-working-onipo-that-could-value-company-at-25-billion-or-more-sources-1475778314

Foucault, Michel. 2008. Security, Territory, Population: Lectures at the College de France 1977-1978. New York: Palgrave.

Flanagan, Mary. 2008. 'Locating Play and Politics: Real World Games \& Activism.' Leonardy Electronic Almanac 16(2-3): 1-13. 
Flanagan, Mary. 2009. Critical Play: Radical Game Design. Cambridge, MA: The MIT Press.

Godlewska, Anne. 'Traditions, Crisis, and New Paradigms in the Rise of the Modern French Discipline of Geography 1760-1850.' Annals of the Association of American Geographers 79(2): 192-213.

Graham Stephen. 2005. 'Software-sorted geographies'. Progress in Human Geography 29: 562-580.

Greene, D.M. and D. Joseph. 2015. 'The Digital Spatial Fix.'triple C: Communication, Capitalism \& Critique 13(2): 223-247.

Gregg, Melissa. 2014. 'Inside the Data Spectacle'. Television \& New Media 16(1): 37-51.

Haggerty, KD and RV Ericson. 2000. 'The Surveillant Assemblage.' The British Journal of Sociology 51(4): 605-622.

Halpern, Orit. 2014. Beautiful Data: A History of Vision and Reason Since 1945. Durham, NC: Duke University Press.

Haraway, Donna. 1991. Simians, Cybords, and Women: The Reinvention of Nature. New York: Routledge.

Harley, J.B. 1989. 'Deconstructing the Map.' Cartographic 26(2). DOI: https:// doi.org/10.3138/E635-7827-1757-9T53

Horkheimer, Max and Theodor Adorno. 2002. Dialectic of Enlightenment. Trans. Edmund Jephcott. Stanford, CA: Stanford University Press.

IBM. 2013. 'Mobile isn't a device. It's data.Available at: https://www.ibm. com/developerworks/community/blogs/c565c720-fe84-4f63-873f607d87787327/resource/mqttdocs/wsj0429opad.pdf?lang=en

Khatib, Abdelhafid. December 1958. 'Attempt at a Psychogeographical Description of Les Halles.' Trans. Paul Hammond. International Situationnniste \#2. Available:http://www.cddc.vt.edu/sionline/si/leshalles.html

Kingsbury, Paul and JP Jones III. 2009. 'Walter Benjamin's Dionysian Adventures on Google Earth.'Geoforum 40: 502-513.

Kitchin, Rob. 2014. The Data Revolution: Big Data, Open Data, Data Infrastructures and Their Consequences. London: Sage.

Kitchin, Rob, and Martin Dodge. 2007. 'Rethinking Maps.' Progress in Human Geography 31(3): 331-344.

Kitchin, Rob, and Tracey Lauriault. 2014. 'Towards Critical Data Studies: Charting and Unpacking Data Assemblages and Their Work.' Forthcoming in Thinking Big Data in Geography: New Regimes, New Research (eds. Jim Thatcher, Joe Eckert, Andy Shears). University of Nebraska Press.

Kitchin, Rob, Tracey Lauriault, and Gavin McArdle. 2015. 'Knowing and Governing Cities Through Urban Indicators, City Benchmarking, and RealTime Dashboards.' Regional Studies, Regional Science 2(1): 729-751.

Leszczynski, Agnieszka. 2014. On the Neo in Neogeography. Annals of the Association of American Geographers, 104:1, 60-79 
Lohr, Steve. 2012. 'Sure, Big Data Is Great, But So Is Intuition.' The New York Times. Available at: http://www.nytimes.com/2012/12/30/technology/bigdata-is-great-but-dont-forget-intuition.html.

Marcus, Greil. 1989. Lipstick Traces. Cambridge, MA: Harvard University Press. Mitchell, W.J.T. 2008. 'The Spectacle Today: A Response to RETORT. Public Culture 20(3): 573-581.

Morozov, Evgeny. 2014. To Save Everything, Click Here: The Folly of Technological Solutionism. New York: PublicAffairs.

Parks, Lisa. 2005. Cultures in Orbit: Satellites and the Televisual. Durham, NC: Duke University Press.

Pavlovskaya, Marianna. 2006. 'Theorizing with GIS: A Tool for Critical Geographies?' Environment and Planning A, 38 (11): 2003-2020. DOI: https:// doi.org/10.1068/a37326

Pickles, John. 2004. A History of Spaces: Cartographic Reason, Mapping and the Geo-Coded World. London: Routledge.

Pinder, David. 1996. 'Subverting Cartography: The Situationists and Maps of the City.' Environment and Planning A 28(3): 405-427.

Plant, Sadie. 1992. The Most Radical Gesture: The Situationaist International in a Postmodern Age. New York: Routledge.

Precarias a la Deriva. 2003. 'First Stutterings of 'Precarias a la Deriva' Available at: https://caringlabor.wordpress.com/2010/12/14/precarias-a-la-derivafirst-stutterings-of-precarias-a-la-deriva/

Precarias a la Deriva. 2006. 'A Very Careful Strike- Four Hypotheses', The Commoner, 11: 33-45

Propen, Amy. 2009. 'Cartographic Representation and the Construction of Lived Worlds: Understanding Cartographic Practice as Embodied Knowledge.' In Rethinking Maps (eds. Martin Dodge, Rob Kitchin, and Chris Perkins) New York: Routledge.

Ranciere, Jacques. 2011. The Emancipated Spectator. Trans. Gregory Elliot. London: Verso.

Rose-Redwood, Reuben. 2015. 'Introduction: The Limits to Deconstructing the Map.' Cartographica: The International Journal for Geographic Information and Geovisualization 50(1): 1-8.

Sadler, Simon. 1999. The Situationist City. Cambridge, MA: The MIT Press.

Schulten, Susan. 2001. The Geographical Imagination in America, 1880-1950. Chicago: Univ. of Chicago Press.

Scott, James C. 1998. Seeing Like a State: How Certain Schemes to Improve the Human Condition Have Failed. New Haven, CT: Yale University Press.

Sieber, Renee. 2006. 'Public Participation Geographic Information Systems: A Literature Review and Framework' Annals of the Association of American Geographers. 96 (3): 455-686 
Singer, Natasha. 2012. 'Consumer data, but not for consumers.' The New York Times. Available at: http://www.nytimes.com/2012/07/22/business/acxiomconsumer-data-often-unavailable-to-consumers. Html

Thatcher, Jim. 2013. 'Avoiding the Ghetto Through Hope and Fear: an Analysis of Immanent Technology Using Ideal Types.' GeoJournal. 78: 967-980.

Thatcher, Jim. 2014. 'Living on Fumes: Digital Footprints, Data Fumes, and the Limitations of Spatial Big Data.'International Journal of Communication. 8: 1765-1783.

Thatcher, Jim. 2016. 'The Object of Mobile Spatial Data, the Subject in Mobile Spatial Research.' Big Data \& Society, July-December: 1-7.

Thatcher, Jim, David O'Sullivan and Dillon Mahmoudi. 2016. 'Data colonialism through accumulation by dispossession: New metaphors for daily data.' Environment and Planning D, Forthcoming. Available at SSRN: https://ssrn. com/abstract $=2709498$

Wark, McKenzie. 2011. The Beach Beneath the Streets: The Everyday Life and Glorious Times of the Situationist International. London, UK: Verso.

Wilmott, Clancy. 2016. 'Small Moments in Spatial Big Data: Calculability, Authority and Interoperability in Everyday Mobile Mapping.' Big Data \& Society July-December 2016: 1-16.

Wilson, Matthew W. 2012. 'Location-based Services, Conspicuous Mobility, and the Location-Aware Future.' Geoforum 43(6): 1266-1275.

Wilson, Matthew W. 2015. 'Flashing Lights in the Quantified Self-City-Nation.' Regional Studies, Regional Science 2(1): 39-42.

Wood, Dennis. 1992. The Power of Maps. New York: Guilford Press.

Wood, Denis. 2010. 'Lynch Debord: About Two Psychogeographies.' Cartographica: The International Journal for Geographic Information and Geovisualization 45(3): 185-199.

Wyly, Elvin. 2014. 'The New Quantitative Revolution.' Dialogues in Human Geography 4(1): 26-38. 